\title{
Image Of Cholesterol Levels In Obesity Patients In Bulukumba District
}

\author{
Ulil Asmi ${ }^{1}$, Arfiani Nur ${ }^{2}$, Asri $^{*}$ \\ DIII Health Analyst Stikes Panrita Husada Bulukumba, Indonesia ${ }^{1}$ \\ University of Islam Negeri Makassar, Indonesia ${ }^{2}$ \\ Nursing Department, Stikes Panrita Husada Bulukumba,Indonesia ${ }^{3}$
}

*Corresponding Autor : nurasri138@yahoo.co.id

\begin{abstract}
Obesity is a condition in which abnormal fat accumulation or excessive adipose tissue so it can be detrimental to health. Diketahuii LDL cholesterol levels in the obese in District ujung loe Bulukumba. Metode district is the method of fully automatic. Principally cholesterol checked after enzymatic hydrolysis and oxidation. Research shows that the results of the LDL-cholesterol levels in 28 obese people showed normal levels of LDL cholesterol as much as 12 samples, high LDL cholesterol levels limit as much as 13 samples, and high cholesterol levels only 3 samples. Of the 28 serum samples obtained from patients with obesity result of normal LDL cholesterol levels as much as 9 samples, high LDL cholesterol levels limit as much as 17 samples, and high cholesterol levels just two samples. For further research should compare the respondent to maintain a diet and exercise regularly. Regular exercise can help you lose excess weight and regulate eating to avoid the various problems due to being overweight include increased levels of LDL in the blood.
\end{abstract}

Keywords: Obesity, Cholesterol, LDL

\section{INTRODUCTION}

Obesity is a condition with abnormal or excessive fat accumulation in the adipose tissue so that it can interfere with health. Central obesity has a strong correlation with insulin resistance. In a state of insulin resistance, lipase sensitivity in adipose tissue will become active so that triglyceride lipolysis in adipose tissue will increase (Fatimawati, 2013). According to the results of the 2018 Riskesdas, the obesity rate in adults in Indonesia increased to $21.8 \%$. This prevalence increased from the results of the 2013 Riskesdas which stated that the obesity rate in Indonesia only reached $14.8 \%$. Obesity itself refers to a condition where the body mass index is 27.0. Likewise, the prevalence of excess body weight with a body mass index between 25.0 and 27.0 also increased from $11.5 \%$ in 2013 to $13.6 \%$ in 2018 . The obesity rate in adults over 18 years according to the results of the 2018 Riskesdas is the highest in North Sulawesi, which was $30.2 \%$. The next highest position was DKI Jakarta 29.8\% East Kalimantan 28.7\% and West Papua 
$26.4 \%$. The prevalence of central obesity among Indonesians has also increased, in 2013 the obesity rate was $26 \%$ and increased to $30 \%$ in 2018.

Based on preliminary data observations from Obesity patients at the Bulukumba Health Office in 2017, cases of Obesity sufferers increased to 65 cases of Obesity sufferers. In 2018 Obesity sufferers decreased to only 35 people with obesity. Overweight and obesity are mainly caused by environmental factors. Genetic factors, although thought to play a role, cannot explain the increasing prevalence of obesity and obesity. The influence of environmental factors mainly occurs through an imbalance between diet, eating behavior, and physical activity. This is mainly related to lifestyle changes that lead to secondary lifestyles (Ministry of Health, 2012). Obesity is considered as the first signal for the emergence of a group of non-infectious diseases that mostly occur in both developed and developing countries. In Indonesia, obesity is a nutritional problem, the prevalence of obesity in people aged $\geq 18$ years based on Body Mass Index (BMI) is $15.4 \%$. Obesity is defined as an increase in body weight above $20 \%$ of normal limits and is associated with abnormal serum lipoprotein levels. Each lipoprotein consists of cholesterol, triglycerides, phospholipids, and apoproteins (Putri and A, 2015).

Obesity has become a health and nutrition problem for the world community in both developed and developing countries. The prevalence of obesity has increased in recent years and has caused serious health problems globally. At least 2.8 million die each year related to weight gain and obesity. Persistent obesity and excessive food intake can cause metabolic system disorders in the form of hypercholesterolemia. Obesity is often associated with hypercholesterolemic conditions. Hypercholesterolemia is a dangerous condition characterized by high cholesterol levels in the blood. Excess cholesterol levels in the blood can cause atherosclerosis, coronary heart disease, stroke, and high blood pressure which can lead to death (Hastuy, 2015). Cholesterol is a component of cell structural membranes and a component of the brain and nerve cells. Cholesterol is stored in the liver. The highest levels of cholesterol are found in the liver and glandular tissue. Cholesterol is needed by bile acids, folic acid, adrenal cortex hormones, estrogen, androgen, and progesterone requires cholesterol. Cholesterol in the body can be obtained from the synthesis in the liver with the main ingredients of carbohydrates, proteins, and fats. The amount of synthesis depends on the amount needed and the amount of cholesterol from food. Cholesterol levels in the blood can form deposits on the walls of blood vessels, causing the narrowing of blood vessels, which is called atherosclerosis. 
Narrowing of the heart blood vessels causes coronary heart disease and when it settles in the blood vessels in the brain it causes cerebrovascular disease (Rinaldy, 2007).

Cholesterol is a lipid derivative that is classified as a steroid or sterol which always binds to other fatty acids in the form of esters. In its separation, it needs to be hydrolyzed through a chemical process by the cholesterol esterase enzyme from the pancreas, as occurs when cholesterol is absorbed in the intestine (duodenum). Cholesterol is the main component of brain and nerve cells and is a building block for several important compounds in the body (Waani et al. , 2016). The increase in blood cholesterol is closely related to coronary heart disease. Hypercholesterolemia usually occurs in obese and elderly people, but it cannot be avoided that this metabolic disorder can occur in lean people even at a young age. Blood cholesterol is an important factor that gives the clearest signs of heart disease. The higher the blood cholesterol level, the greater the risk of death as a result of the hardening of the coronary arteries (Widada and Carolina, 2016).

It is known that cholesterol levels in obese people will cause serious health problems. Persistent obesity and excessive food intake can cause metabolic system disorders in the form of hypercholesterolemia. Obesity and overweight have become epidemic diseases that threaten the world and are secondary factors for the onset of coronary heart disease (CHD) (sinaga et al, 2013). Excess cholesterol levels in the blood can cause atherosclerosis, coronary heart disease, stroke, and high blood pressure which can lead to death (Hastuty, 2015). The purpose of this study was to know the levels of LDL cholesterol in obese patients in Ujung loe sub-district, Bulukumba Regency.

\section{MATERIAL AND METHODS}

The research design used in this research is descriptive analysis design with the method of observation with a cross sectional approach. The population is a whole collection of elements that we can use to make some conclusions (Siswanto, 2017). The population in this study were all people with obesity in Bulukumba Regency. Sampling in this study using a sampling technique, namely purposive sampling is a sampling technique, where samples are taken from people who come from a specific group, then searched and sampled (Swarjana, 2015).

The instrument used in this study is to use primary data which is obtained from research subjects using measurement tools or direct data collection tools on the subject as the source of information sought (Susila and Suyanto, 2014). Primary data is data derived from cholesterol checks in obese patients in Ujungloe District, Bulukumba 
Regency. And secondary data is data obtained through other parties, not directly obtained by researchers from the research subject. Secondary data is usually in the form of documentation data or available report data (Susila and Suyanto, 2014. Secondary data is data that comes from journals, as well as literature containing research. The data obtained from this study were discussed in a descriptive laboratory in tabular form.

\section{RESULTS}

Table 1. Characteristic distribution of respondents according to age and sex in Ujungloe District

\begin{tabular}{ccc}
\hline Characteristics Age & Frequency (n) & Percent (\%) \\
\hline Youth (17-25) & 6 & 21,4 \\
Adult (26-45) & 20 & 71,4 \\
Elderly (46-65) & 2 & 7,1 \\
Gender & & \\
Male & 21 & 21,4 \\
Women & 22 & 78,6 \\
Total & 28 & 100 \\
\hline
\end{tabular}

Based on table 4.1 shows that most of the respondents are aged 26-45 with a frequency of 20 respondents (71.4\%). And most of the respondents were female with a frequency of 22 respondents (78.6\%).

Table 2. Distribution of samples based on cholesterol levels in Ujungloe District

\begin{tabular}{ccc}
\hline Cholesterol category $(\mathrm{mg} / \mathrm{dl})$ & Frequency $(\mathrm{n})$ & Percent $(\%)$ \\
\hline Normal $(<100)$ & 10 & 35,7 \\
High limit $(129-159)$ & 16 & 57,1 \\
High $(160-190)$ & 2 & 7,1 \\
\hline Total & $\mathbf{2 8}$ & $\mathbf{1 0 0}$ \\
\hline
\end{tabular}

Based on table 4.2, it shows that most of the respondents with high limit LDL cholesterol levels were $129-159$ with a frequency of 16 respondents (57.1\%).

\section{DISCUSSION}

The results of the study conducted on 28 respondents who were residents of the Ujungloe sub-district showed normal Low-density lipoprotein (LDL) cholesterol levels were 10 people (32.1\%) with levels $<100 \mathrm{mg} / \mathrm{dl}$, high limit LDL cholesterol levels were 16 people $(60,7)$ with levels of $129-159 \mathrm{mg} / \mathrm{dl}$ and high levels of LDL cholesterol, there were 2 people (7.1\%) with high LDL $160-190 \mathrm{mg} / \mathrm{dl}$. This study took samples of respondents with a BMI of $25.0->30 \mathrm{~kg} / \mathrm{m} 2$.

The results of this study are related to the characteristics of the respondents. It was found that the most age categories of respondents were in the adult age range (26-45) years (74.4\%). It was found that more female samples were obese (78.6\%) than men who 
were obese (21.4\%). This is possible because the average respondent is around the age of 26-45 years, a study that is in line with this study by the results of Yulina Dwi Hastuty's research that high cholesterol levels are in the age range above 30 years. And another study that is in line with this study by Nur Rahma Musdalifa's research that there is a relationship between cholesterol levels and the age of a person at an older age, cholesterol levels are higher than young people. Besides, the majority of the sample is female, who is mostly obese (78.6\%). This study is in line with Christoffel's study eliminating that there were fewer male samples with overweight and obesity (43.3\%) compared to the sample with the female who is overweight or obese $(59.1 \%)$. This is because in women it is related to the hormone estrogen, where the hormone estrogen is also associated with cholesterol formation. LDL is a lipoprotein that transports cholesterol to body cells that need it, where if the levels are excessive, it will harm health. One of the factors that can increase LDL levels is obesity. Obese people experience excessive fat accumulation in the body. The cause of obesity is usually due to an abnormal diet, namely eating very large amounts and eating at night (Andri Sukeksi, 2010). Cholesterol at normal levels is a major component of cell walls and bile. Another function is forming acid and bile salts, consumption of foods high in fat and cholesterol will increase total cholesterol levels and LDL levels. The liver will have sufficient cholesterol levels and will stop taking LDL which can increase cholesterol levels (Herliana, 2010).

Obese people do not always have high cholesterol levels. High cholesterol is always influenced by obesity, but it can be influenced by the consumption of foods that contain lots of cholesterol, such as eating meat and eggs, which contain high enough cholesterol. Increased consumption of fast food (fast food), low physical activity, genetic factors, the influence of advertising, psychological factors, socioeconomic status, diet programs, age, and sex are all factors that contribute to changes in energy balance and lead to obesity (weni kurdanti, 2015). In cholesterol disease, LDL levels in the blood increase beyond normal limits which can cause fat to stick to the walls of blood vessels. This situation can cause narrowing of blood flow which is called atherosclerosis. Atherosclerosis can increase blood pressure so that sufferers can also develop hypertension. Willingness to live a healthy life, discipline, and the use of certain drugs can help people with obesity to lose weight, thereby preventing more severe complications of obesity (Christoffel Elim, 2012). 
From the results of the above research, it was found that the highest cholesterol levels were at the high limit of 16 people (57.1\%). From previous researchers by Inda V.M. Rawung showed that 4 boys and 23 girls with a total of 27 students (50\%) had LDL levels.

\section{CONCLUSION}

From the results of research conducted in the Ujungloe sub-district, Bulukumba district, from 28 serum samples obtained from obese patients, it can be concluded that the cholesterol level results tend to be at the high limit. For future researchers, it is better to compare with respondents to maintain their diet and do regular exercise. Regular exercise can help you lose excess weight and adjust your meal portions so you can avoid various problems due to excess weight, including increased levels of LDL in the blood. For districts/cities, carry out regular exercise programs and a healthy lifestyle to prevent obesity.

\section{REFERENCES}

Andri Sukeksi, H. A. 2010. Kadar kolesterol darah pada penderita obesitas di kelurahan korpri sambiroto semarang jurnal unimus.ac.id.

Dharma, K. K. 2011. Metodologi Penelitian Keperawatan, CV. Trans Info Media.

Christoffel Elim, D. H. C. P., Siantan Supit, Vellisia Lindo, Sarah M. Warouw 2012.

Gambaran kadar low density lipoprotein (LDL) pada siswa-siswi overweight dan obesitas di kota manado. Jurnal biomedik, 4.

Fatimawati, N. I. D. A. E. M. 2013. Gambaran kadar trigliserida pada remaja obes di kabupaten bulukumba. Jurnal e-biomedik1, 537-542.

Febry, A. B., Pujiastuti, N. \& Fajar, I. 2013. Ilmu gizi untuk praktisi kesehatan, Yogyakarta.

Hastuty, Y. D. 2015. Perbedaan kadar kolesterol oang yang obesitas dengan orang yang non obesitas 1 .

Kemenkes 2012. Pedoman penceghan dan penanggulangan kegemukan dan obesitas.

Misnadiarly 2011. Obesitas Sebagai Faktor Risiko Beberapa Penyakit, Jakarta, Pustaka Obor.

Panil, D. Z. 2008. Memahami Teori Dan Praktik Biokimia Dasar Medis, Jakarta, Buku Kedokteran EGC.

Putri, S. R. \& A, D. I. 2015. Obesitas Sebagai Faktor Resiko Peningkatan Kadar Trigliserida. $4,78$. 
Setyawati, V. A. V. \& hartini, e. 2018. Buku Ajar Dasar Ilmu Gizi Kesehatan Masyarakat, Yogyakarta, Cv Budi Utama.

Siswanto, S., Suyanto 2017. Metodologi Penelitian Kombinasi Kualitatif - Kuantitatif Kedokteran Dan Kesehatan, Bossscript.

Sugiyono 2012. Metode Penelitian Kuantitatif, Kualitatif, Dan R\&D. Bandung: Alfabeta, CV.

Sumbono, A. 2016. Biokimia Pangan Dasar, Deepublish.

Swarjana, K. 2015. Metodologi Penelitian Kesehatan, Yogyakarta, CV. Andi Offset.

Tjay, d. T. H. \& rahardja, d. K. 2010. Obat-Obat Sederhana Untuk Gangguan Sehari-Hari, Jakarta, PT Elex Media Komputindo.

Waani, O. T., Tiho, M. \& Kaligis, S. H. M. 2016. Gambaran kadar kolesterol total darah pada pekerja kantor. Junal e-biomedik, 4.

Widada, s. T. \& Carolina, m. A. M. S. C. 2016. Gambaran perbedaan kadar kolesterol total metode CHOD -PAP (Cholesterol oxidase-peroxsidae aminoantypirin ) sampel serum dan sanmpel plasma EDTA. Jurnal tekhnologi penelitian, 5, 41-44.

Misnadiarly 2011. Obesitas Sebagai Faktor Risiko Beberapa Penyakit, Jakarta, Pustaka Obor.

Weni Kurdanti, I. S., Nurul Hada Syamsiatun, Listiana Purnaning Siwi, Mahardika Marta Adityanti, Diana Mustikaningsih, Kurnia Isnaini Sholihah 2015. Faktor-faktor yang mempengaruhi kejadian obesitas pada remaja jurnal gizi klinik indonesia, 11. 